\title{
THE LATE DEVELOPMENT EFFECT: A REPLY
}

\section{Ronald Dore}

Susantha Goonatilake's article points up, I suppose, the dangers of trying to attract attention with jazzy labels like 'late development effect' which are given more attention than the ideas that underlie them. First, then, a little clarification. When I wrote of a 'late development effect' (IDS Communication no. 103) I used it as a label for propositions of the kind: ("the later in world history that a deliberate development drive starts, the more ...) I suggested several dependent clauses; ... the more the State is involved in the economy (the Gerschenkron insight which set me off on that track); . . the more educational qualifications are used to allocate jobs; . . the more unlikely a country is to develop wage and industrial relations systems like Britain's. Note that the mechanisms do not only involve the one on which Susantha Goonatilake concentrates - direct cultural borrowing. Much depends also on other factors like the increasing interdependence of national economies, the increasing technical possibilities of mortality control and growing population increase rates, increasing technical possibilities of rapid and cheap communications, etc.

The particular hypotheses about a late developer's likely pattern of employment relations I have set out elsewhere in this issue. There were two kinds of hypotheses; one, clearly testable, about the sort of institutional forms one was likely to find in the modern sector industry of capitalist late-developers: low turnover of permanent workers, wage and promotion systems that provide workers with some kind of steady career progression, a good deal of enterprise welfare, an enterprise-unit basis of trade union organization and collective bargaining etc. When Susantha Goonatilake writes up the results of the research we did in Sri Lanka, I think the answer will be that some features do not fit expectations - notably I had underestimated the importance of the state and legal processes - but a very great many of them do.

The issue lies in the other set of hypotheses - about why this should be so. Perhaps, since I have clearly not made myself sufficiently understood, I should say briefly what my assumptions actually were. First, I assumed that a lot was to be explained by the common 'logic of 
the situation' of late developing countries; the demographic situation, the training needs for sophisicated imported technology; or the fact that educational systems are built faster than modern industry - i.e. not only by the transfer of social technology. Secondly, as for the modes of such transfer, I assumed that there are crucial stages in the history of a country's industrialization when employment institutions, patterns of industrial relations, etc., take a definite shape, after which change becomes more gradual - Japan had such a period in the 1920 s and again in the late 1940s; Sri Lanka, I suppose, in the late 1940s and 1950 s. The institutions thus built are likely to embody whatever is the dominant received wisdom about the 'best' practices currently preached in those of the early-starter countries which currently have the highest prestige as being 'ahead'. Note that I say 'preached'; not practised. I doubt if the Industrial Society in Bryanston Square would claim that the latest wisdom which it purveys on its personnel management courses for people from the Third World, represents current British practice!

So, to deal with some of Susantha Goonatilake's points, I do not assume that what is copied are early-starter average practices (his perpetual leapfrog game scenario), I do not assume, bless him, that England is the only source of the latest wisdom, and I do not assume that the content of the transfer is fixed. I would have thought all this was clear from those bits of me he quotes in his third paragraph and third footnote.

Nor, to finish listing my non-assumptions, do I assume that imported social technologies 'override the existing local one'. (I could hardly do so - after all I have written in my book on Japanese and British factories about the residual Japaneseness of Japanese institutions which the circumstances of late development do not explain nor do I assume that those elements of imported ideas which relate to the granting of trade union and worker rights, are always 'peacefully' imported without any of the prospective beneficiaries lifting a finger to get them. What I would argue, however, is that the change in 'world norms' embodied in ILO Conventions - as a result of the victories of trade union movements in the early-starters - alters the nature of the struggle in the late-starters. If one compares the fight of British trade unions over the seventy years it took to move from the Combination Acts, which 
outlawed them, to the Trade Disputes Act of 1906, with the intensity of that struggle in Sri Lanka, I would have thought it obvious that even during the colonial period and certainly after Independence, Sri Lanka's governments and capitalists were a push-over compared with the 19 th century British governments and capitalists.

But Susantha Goonatilake's main attack concentrates on my assumption - which I freely admit - that most diffusion of social technology and social ideas (I agree with him that they usually go packaged together) goes from the richer 'advanced' early starters to the 'follower' poorer late-starters. I'm afraid I remain unmoved from this assumption by his arguments about Maslow's interest in Buddhism or the similarity (?) between flexitime and peasant time. And in any case it is clearly in the last paragraph that his main objections are revealed. It is not the empirical truth of the assumption that matters but the consequences of acknowledging it. If, he suggests, people in Sri Lanka, say, accept such a thesis as true they would be accepting cultural domination as legitimate.

I would have thought the contrary was true. If historical analysis shows a general tendency in late-developers to 'borrow the advanced country latest', irrespective of its appropriateness, then I would have thought that an awareness of this tendency is the best prophylactic against it. One should be better able to pick and choose if one is armed with a suitable general scepticism about 'the rich country latest' - whether that be the latest labour-saving technology, the most fashionable middle-class radicalism, or the new 'loosely structured' organizational ideology to be found in the work of the impressive range of authors whom Susantha cites. (I make, of course, no prejudgement as to whether they are likely to be deemed appropriate or not).

As for the other side of the coin - whether for me to talk about these mechanisms of cultural transmission amounts to imperialism; well, I suppose that depends on one's definition of imperialism. 